\title{
Honokiol inhibits the growth of SKBR3 cells
}

\section{He Shi", Yange Wang", Mengli Yao, Dian Zhang, Wenli Fang, Ting Zhou, Delu Gan, Shujun Yue, Husun Qian, Tingmei Chen}

Key Laboratory of Clinical Laboratory Diagnostics (Ministry of Education), College of Laboratory Medicine, Chongqing Medical University, Chongqing, China

Contributions: (I) Conception and design: H Shi; (II) Administrative support: T Chen; (III) Provision of study materials or patients: H Shi, Y Wang, M Yao, D Zhang, W Fang, T Zhou, D Gan, S Yue, H Qian; (IV) Collection and assembly of data: H Shi; (V) Data analysis and interpretation: H Shi; (VI) Manuscript writing: All authors; (VII) Final approval of manuscript: All authors.

\#These authors contributed equally to this work.

Correspondence to: Tingmei Chen. Key Laboratory of Clinical Laboratory Diagnostics (Ministry of Education), College of Laboratory Medicine, Chongqing Medical University, Chongqing 400016, China. Email: tingmeichen@cqmu.edu.cn.

Background: Breast cancer is one of the most malignant tumors in the reproductive system and has a poor prognosis. Finding drugs with high efficiency, low side-effects, and low cost has become a research hotspot.

Methods: In the present study, we treated SK-BR-3 cells with different doses of honokiol. Crystal violet staining method was used to detect changes in the total number of living cells; 3-(4,5-dimethylthiazol2-yl)-2,5-diphenyltetrazolium bromide assay was used to detect the effect of honokiol on SK-BR-3 cell proliferation. Cell migration ability change was determined by wound healing assay. Cell invasion ability change was determined by Transwell migration assay. Flow cytometry was used to detect the apoptotic rate of SK-BR-3 cells, and Western blot was used to detect the expression levels of proliferation-associated protein (PCNA); migration- and invasion-related protein matrix metalloproteinase-2 (MMP-2); vimentin; apoptosis-related proteins $\mathrm{Bcl}-\mathrm{xl}$, caspase 3 , and cleaved caspase 3 (CC3); and $\beta$-catenin and its downstream target molecule c-Myc.

Results: Compared with the control group, different doses of honokiol have different degrees of inhibitory effects on cells, including proliferation and invasion and migration $(\mathrm{P}<0.01)$. After treatment with 50 or $60 \mu \mathrm{mol} \cdot \mathrm{L}^{-1}$ honokiol, the apoptotic rate of SK-BR-3 cells increased (both $\mathrm{P}<0.01$ ); PCNA expression was significantly downregulated $(\mathrm{P}<0.01)$. Intracellular accumulation of apoptosis-related proteins $\mathrm{Bcl}-\mathrm{xl}$ and caspase-3 decreased but C-C3 increased. We also found downregulation of MMP-2 expression, a protein related to invasion and migration $(\mathrm{P}<0.01)$, and a decrease in the expression levels of the Wnt/ $\beta$-catenin signaling pathway-related proteins $\beta$-catenin and $c-M y c(P<0.01)$.

Conclusions: Honokiol can promote the apoptosis of SK-BR-3 cells and can inhibit the proliferation, migration, and invasion of human breast cancer SK-BR-3 cells. The underlying mechanism may be through inhibiting the activation of the Wnt signaling pathway.

Keywords: Breast cancer; honokiol; cell proliferation; apoptosis; SK-BR-3 cells

Submitted Sep 18, 2020. Accepted for publication Nov 24, 2020.

doi: $10.21037 /$ tcr-20-3110

View this article at: http://dx.doi.org/10.21037/tcr-20-3110

\section{Introduction}

Breast cancer is the most common cancer among women worldwide. The current treatment methods for breast cancer mainly include surgical removal of the lesion, postoperative radiotherapy and chemotherapy, and drug maintenance (1-3). However, despite these treatment modalities, breast cancer still has a poor prognosis and a high rate of recurrence. As well as the financial pressures associated with breast cancer, the side-effects of drugs are 
also an issue for patients. Therefore, it is important to find a drug with high efficiency, low-side effects, and low cost for the treatment of breast cancer.

Honokiol is a biologically active ingredient isolated from the Chinese herbal medicine magnolia, which can effectively inhibit the growth of tumor cells. According to the literature, honokiol can induce apoptosis in pancreatic and gastric cancer cells $(4,5)$, and can also inhibit the growth and metastasis of melanoma (6). Current breast cancer research is limited to the effects of honokiol on the two human epidermal growth factor receptor 2 (HER2)-negative cell lines MDA-MB-231 and MCF-7 $(7,8)$. The role and mechanism of honokiol in breast cancer SK-BR-3 cells have not yet been reported. SK-BR-3 cells were isolated from the pleural effusion of a 43 white female breast cancer patient in 1970, It is an epithelioid adherent cell. As a landmark breast cancer cell, SK-BR-3 cells have been used as experimental objects in many studies (9-11). SK-BR-3 cells are breast cancer cells with high HER2 expression. HER2-positive breast cancer has a high rate of recurrence and metastasis, as well as poor prognosis (12). Finding anti-tumor drugs that can effectively inhibit the growth of SK-BR-3 cells is important for the treatment of breast cancer. Therefore, in the present study, we used different concentrations of honokiol to treat breast cancer SK-BR-3 cells to observe its effects on the proliferation, apoptosis, invasion, and migration of SK-BR-3 cells, and to detect the changes in expression in Wnt signaling pathway-related proteins $\beta$-catenin and C-Myc. This can provide new evidence that honokiol can be used as an anti-tumor drug to effectively treat breast cancer. We present the following article in accordance with the MDAR reporting checklist (available at http://dx.doi.org/10.21037/tcr-20-3110).

\section{Methods}

\section{Cell culture}

SK-BR-3 cells (Procell, Wuhan, China) cell culture medium formulation: Dulbecco's modified Eagle's medium, fetal bovine serum (Gibco, USA), streptomycinpenicillin (Gibco). Drug treatment: Honokiol (Chengdu Herbpurify, China, Art.No:35354-74-6) were dissolved in dimethylsulfoxide (DMSO), then stored at $-80{ }^{\circ} \mathrm{C}$ under dark conditions.

\section{Crystal violet staining}

SK-BR-3 cells with good morphology and growth were selected; $3 \times 10^{4}$ cells $(500 \mu \mathrm{L})$ were inoculated in a 24 -well plate, and the plate was shaken. After $12 \mathrm{~h}$, when the cells had grown to $40 \%$, they were treated with honokiol at concentrations of 40,50 , and $60 \mu \mathrm{mol} \cdot \mathrm{L}^{-1}$. After processing for 48 and $72 \mathrm{~h}$, the medium was discarded from the 24-well plate. A total of $500 \mu \mathrm{L}$ of $4 \%$ paraformaldehyde solution was added and fixed in a $37^{\circ} \mathrm{C}$ incubator for $25 \mathrm{~min}$. The paraformaldehyde was discarded and $700 \mu \mathrm{L}$ crystal violet staining solution was added to each well and left for 10 min under dark conditions before the crystal violet staining solution was discarded. The dye was washed, and the plate was scanned after drying. A total of $200 \mu \mathrm{L}$ of $10 \%$ glacial acetic acid solution was then added to each well and shaken at room temperature for $15 \mathrm{~min}$. Absorbance of each well at a wavelength of $590 \mathrm{~nm}$ was detected with an enzyme-linked immunoassay, and the cell proliferation inhibition rate was calculated using the following equation: Proliferation inhibition rate $(\%)=($ control group absorbance value - medication group absorbance value)/control group absorbance value $\times 100 \%$.

\section{3-(4,5-dimethylthiazol-2-yl)-2,5-diphenyltetrazolium bromide (MTT) assay}

In total, 5,000 cells (constant volume to $100 \mu \mathrm{L}$ ) were counted and inoculated evenly on 96-well plates. Cells were treated with different concentrations of honokiol for 48 and $72 \mathrm{~h}$, and then $10 \mu \mathrm{L}$ MTT solution was added to each well, place the 96-well plate flat in the incubator and continued to incubate for $4 \mathrm{~h}$. A total of $100 \mu \mathrm{L}$ DMSO was added to each well, protected from light, shake the 96-well plate $10 \mathrm{~min}$ at room temperature, set the wavelength to $492 \mathrm{~nm}$, and measure the absorbance of each well with an enzyme-linked immunoassay to reflect the cell proliferation activity.

\section{Wound bealing assay}

The cells were inoculated in 6-well plates until the cells cover the entire plate. A $200 \mu \mathrm{L}$ pipette tip was used to make a vertical scratch on the cell culture plate. Floating cells were removed by washing with phosphate-buffered saline (PBS). A total of $2 \mathrm{~mL}$ of serum-free medium was slowly added along the wall, and the SK-BR-3 cells were treated with concentrations of 40, 50, $60 \mu \mathrm{mol} \cdot \mathrm{L}^{-1}$ honokiol. A blank control and DMSO control were set, and pictures were taken at 0 and $48 \mathrm{~h}$ to compare the position of the cell. After $48 \mathrm{~h}$, the scratch area was recorded by taking pictures. Wound healing rate $(\%)=(0 \mathrm{~h}$ scratch area $-48 \mathrm{~h}$ scratch 
area) $/ 0 \mathrm{~h}$ scratch area $\times 100 \%$, this reflects the ability of cells to migrate.

\section{Transwell assay}

SK-BR-3 cells with good morphology and growth were selected, digested with trypsin, and resuspended in serumfree medium for later use. Matrigel was added to the upper chamber (1:8 dilution; BD Biosciences), and $400 \mu \mathrm{L}$ of cell suspension containing $2.2 \times 10^{4}$ cells was added to the upper layer of the Transwell chamber. The SK-BR-3 cells were treated with $40,50,60 \mu \mathrm{mol} \cdot \mathrm{L}^{-1}$ honokiol; the blank control and DMSO control were set at the same time. After culturing for $48 \mathrm{~h}$, invading cells were fixed, stained with crystal violet, imaged, and counted under a microscope.

\section{Flow cytometry cell apoptosis analysis}

Cells were treated with different concentrations of honokiol. After $48 \mathrm{~h}$, the cells were digested and collected with trypsin without ethylenediaminetetraacetic acid. The cells were resuspended in PBS after centrifugation and then treated with Annexin V-allophycocyanin (APC; BD Pharmingen, USA) and propidium iodide (PI; BD Pharmingen, USA) under dark conditions. Positive cells were identified as apoptotic by flow cytometry.

\section{Western blot}

Cells were collected after treatment with honokiol for $48 \mathrm{~h}$ and the protein concentration was measured. The electrophoresis step is to run at $70 \mathrm{~V}$ for 40 minutes and then at $100 \mathrm{~V}$ for $1 \mathrm{~h}$. The cells were then blocked with bovine serum albumin for $2 \mathrm{~h}$ at room temperature. The following primary antibodies were used: $\alpha$-tubulin), $\beta$-actin (1:1,000; Proteintech), Bcl-xl, proliferation-associated protein (PCNA), $\beta$-catenin, matrix metalloproteinase- 2 (MMP-2), vimentin, caspase 3, cleaved caspase 3 (CC3; 1:1,000; Cell Signaling Technology), c-Myc (1:1,000; Abcam). Horseradish peroxidase-conjugated goat antimouse or rabbit immunoglobulin G $(1: 5,000$; absin, Shanghai, China).

\section{Statistical analysis}

Each experiment was repeated 3 times independently. Data are expressed as mean \pm standard deviation. Oneway analysis of variance was used to analyze the datasets in the group. Use GraphPad Prism 8 software (GraphPad Software, USA) for date processing. $\mathrm{P}<0.05$ indicated a statistically significant difference.

\section{Results}

\section{Honokiol inhibits the proliferation of human SK-BR-3 cells}

After treating SK-BR-3 cells with different concentrations of honokiol $\left(40,50,60 \mu \mathrm{mol} \cdot \mathrm{L}^{-1}\right)$ for $48 \mathrm{~h}$ and $72 \mathrm{~h}$, the total number of cells was detected by crystal violet staining. The results are shown in (Figure 1A). After treatment with $40 \mu \mathrm{mol} \cdot \mathrm{L}^{-1}$ honokiol, the total number of cells decreased compared with the control group. When treated with 50 and $60 \mu \mathrm{mol} \cdot \mathrm{L}^{-1}$ honokiol, the total number of cells further decreased $(\mathrm{P}<0.01)$. Further MTT measurement results are shown in (Figure 1B). Compared with the blank control group, 40,50 , and $60 \mu \mathrm{mol} \cdot \mathrm{L}^{-1}$ honokiol was found to significantly inhibit the proliferation activity of SK-BR-3 cells $(\mathrm{P}<0.01)$. We recorded the morphology of SK-BR-3 cells after treatment with different concentrations of honokiol (Figure 1C), we found that as the treatment concentration increases, the overall number of cells decreases, and the cell state gradually deteriorates. Specifically, vacuoles appear in the cells, the cell shape becomes round, and some cells are broken. In addition, we treated SK-BR-3 cells with different concentrations of honokiol for $48 \mathrm{~h}$ to extract total protein (Figure 1D). When SK-BR-3 cells were treated with 50 and $60 \mu \mathrm{mol} \cdot \mathrm{L}^{-1}$ honokiol, the expression level of cell proliferation-related protein PCNA was significantly lower than that of the blank control group $(\mathrm{P}<0.01)$. These results indicate that honokiol can inhibit the proliferation of human breast cancer SK-BR-3 cells, and the inhibitory effect is concentration dependent.

\section{Honokiol promotes apoptosis of SK-BR-3 cells}

To investigate the effect of honokiol on the degree of SKBR-3 cell apoptosis. After treating SK-BR-3 cells with different concentrations of honokiol $\left(40,50,60 \mu \mathrm{mol} \cdot \mathrm{L}^{-1}\right)$ for $48 \mathrm{~h}$, apoptosis was detected by flow cytometry (Figure $2 A$ ). The apoptotic rate of the 50 and $60 \mu \mathrm{mol} \cdot \mathrm{L}^{-1}$ honokiol treatment groups was significantly higher than that of the blank control group $(\mathrm{P}<0.01)$. The results of Western blot are shown in Figure 2B. After treatment of SK-BR-3 cells with 50 and $60 \mu \mathrm{mol} \cdot \mathrm{L}^{-1}$ honokiol, the expression level of the apoptosis-related protein CC3 significantly increased, while the expression level of caspase 3 decreased; the anti- 
A

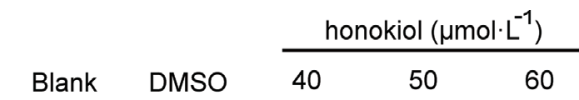

$48 h$

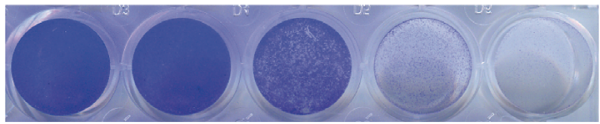

$72 \mathrm{~h}$

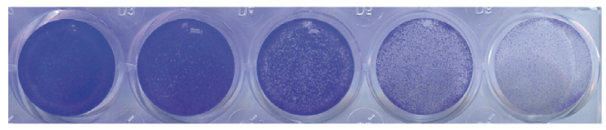

B

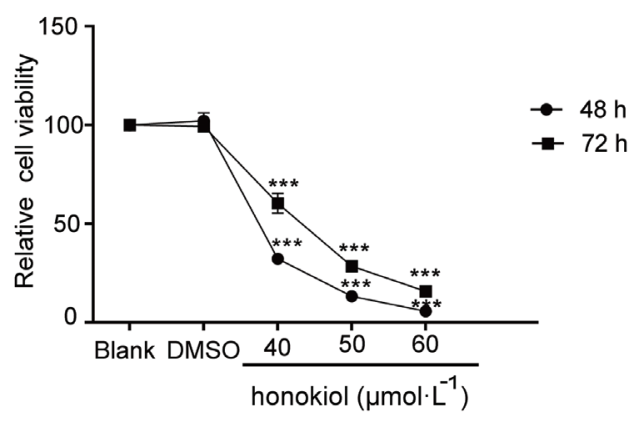

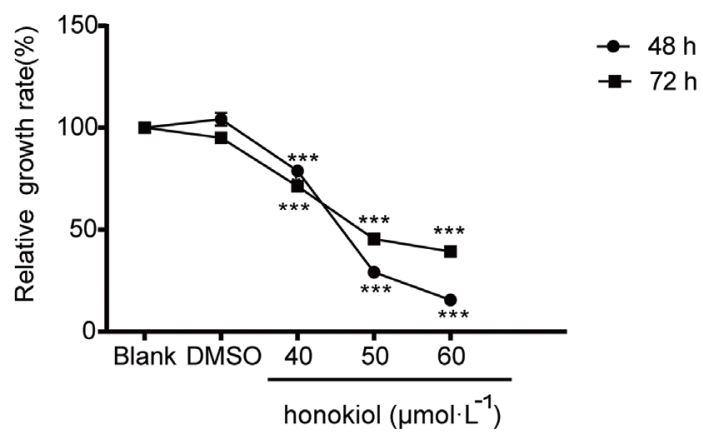

C

honokiol $\left(\mu \mathrm{mol} \cdot \mathrm{L}^{-1}\right)$

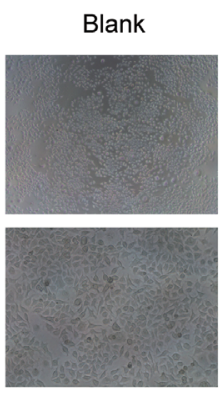

DMSO
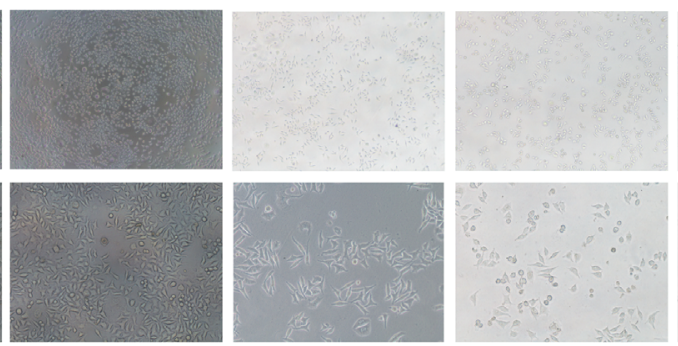

60

D
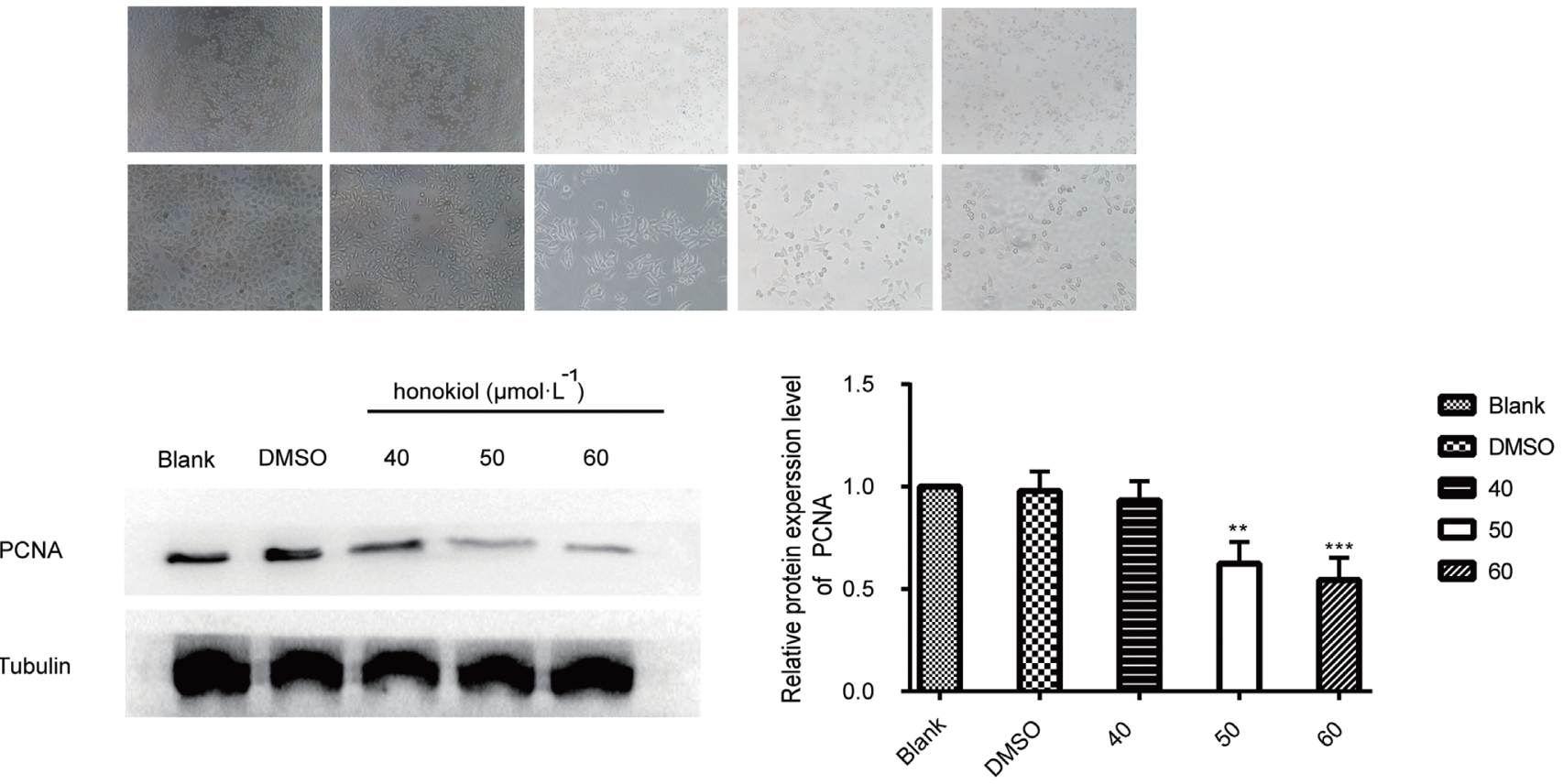

PCNA

a-Tubulin

Figure 1 Honokiol effectively inhibits the proliferation of human breast cancer SK-BR-3 cells. (A,B) Total number and cell viability of SKBR-3 cells treated with different concentrations of honokiol for $48 \mathrm{~h}$ was detected by crystal violet staining and 3-(4,5-dimethylthiazol-2yl)-2,5-diphenyltetrazolium bromide assay. (C) Morphology of SK-BR-3 cells after treatment with different concentrations of honokiol. (D) Protein expression level of proliferation-associated protein (PCNA) after honokiol treatment. Each experiment was repeated 3 times. Oneway analysis of variance was used for the statistical analysis. Data are expressed as mean \pm standard deviation. $\mathrm{P}<0.05$ indicates a statistically significant difference. ${ }^{* *} \mathrm{P}<0.01,{ }^{* * *} \mathrm{P}<0.001$. DMSO, dimethylsulfoxide. 
A

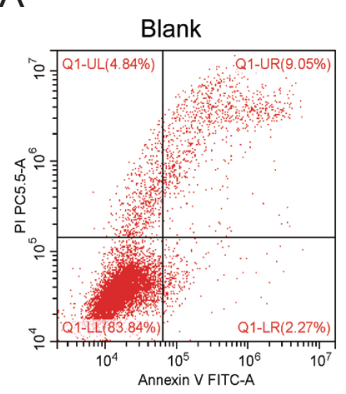

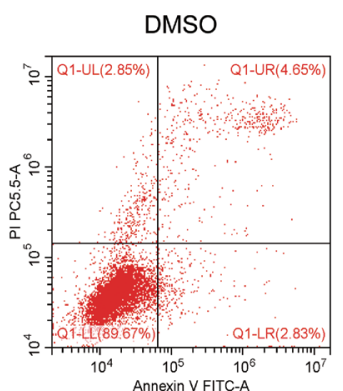
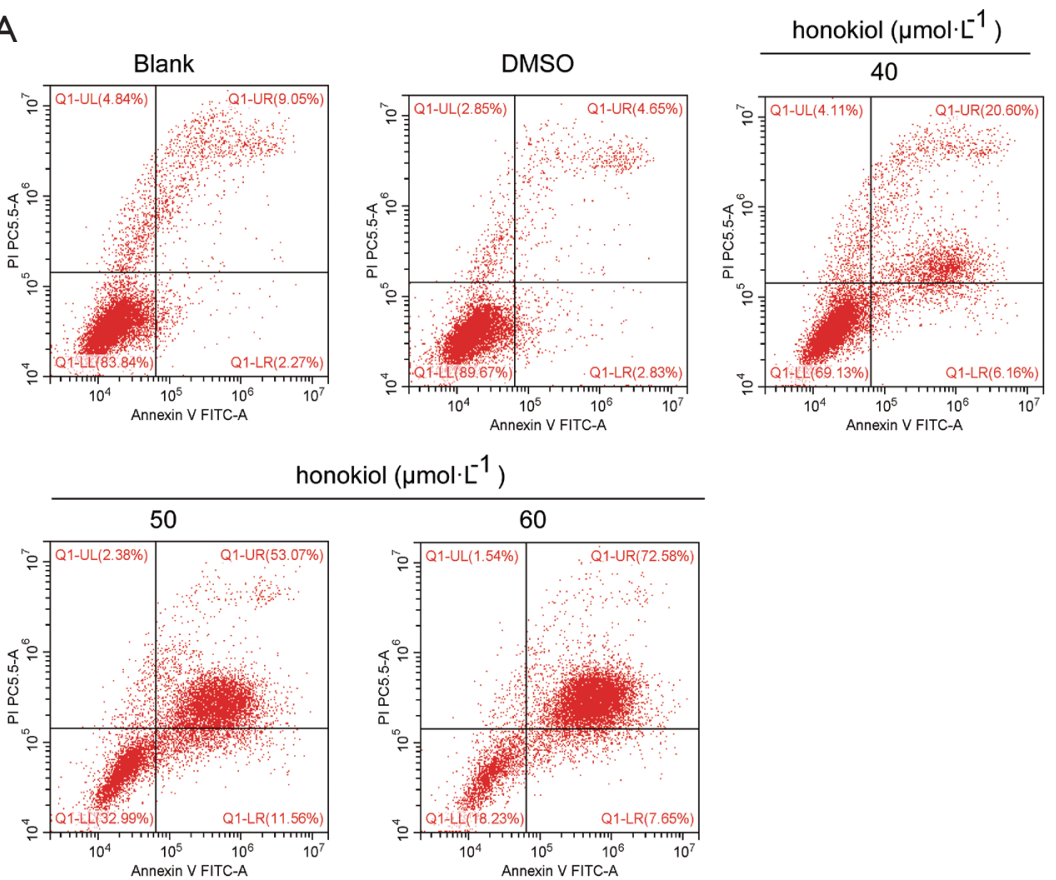

honokiol $\left(\mu \mathrm{mol} \cdot \mathrm{L}^{-1}\right)$

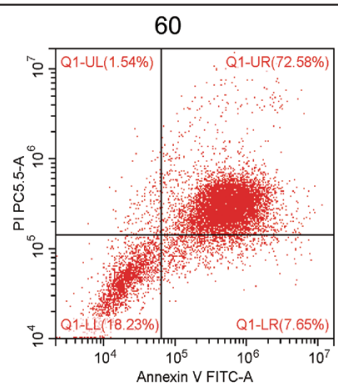

\section{B}

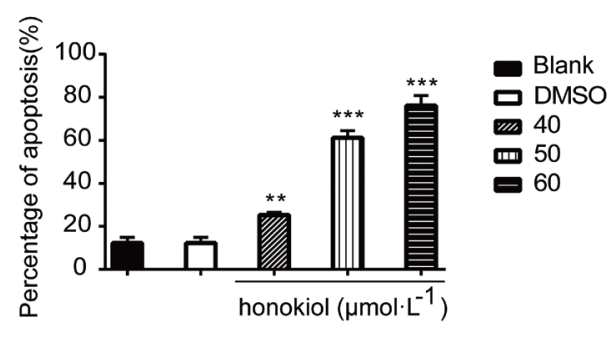

C
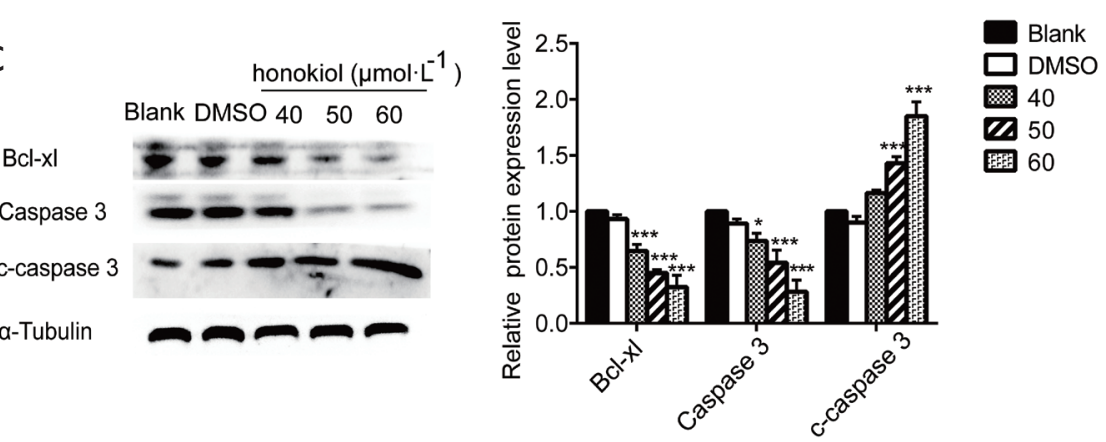

Figure 2 Honokiol significantly promotes the apoptosis of human breast cancer SK-BR-3 cells. (A) Apoptosis of SK-BR-3 cells treated with different concentrations of honokiol for $48 \mathrm{~h}$ were then detected by flow cytometry. (B) Protein expression level of Bcl-xl, caspase 3, and cleaved caspase 3. Each experiment was repeated 3 times. One-way analysis of variance was used for the statistical analysis. Data are expressed as mean \pm standard deviation. $\mathrm{P}<0.05$ indicates a statistically significant difference. ${ }^{*} \mathrm{P}<0.05,{ }^{* *} \mathrm{P}<0.01,{ }^{* * *} \mathrm{P}<0.001$. DMSO, dimethylsulfoxide.

apoptosis-related protein $\mathrm{Bcl}-\mathrm{xl}$ also had a significant decline $(\mathrm{P}<0.05)$. These results indicate that honokiol can promote the apoptosis of human breast cancer SK-BR-3 cells, and the inhibitory effect is concentration dependent.

\section{Honokiol inbibits the invasion and migration of SK-BR-3} cells

After treating SK-BR-3 cells with different concentrations of honokiol $\left(40,50,60 \mu \mathrm{mol} \cdot \mathrm{L}^{-1}\right)$ for $48 \mathrm{~h}$, wound healing 


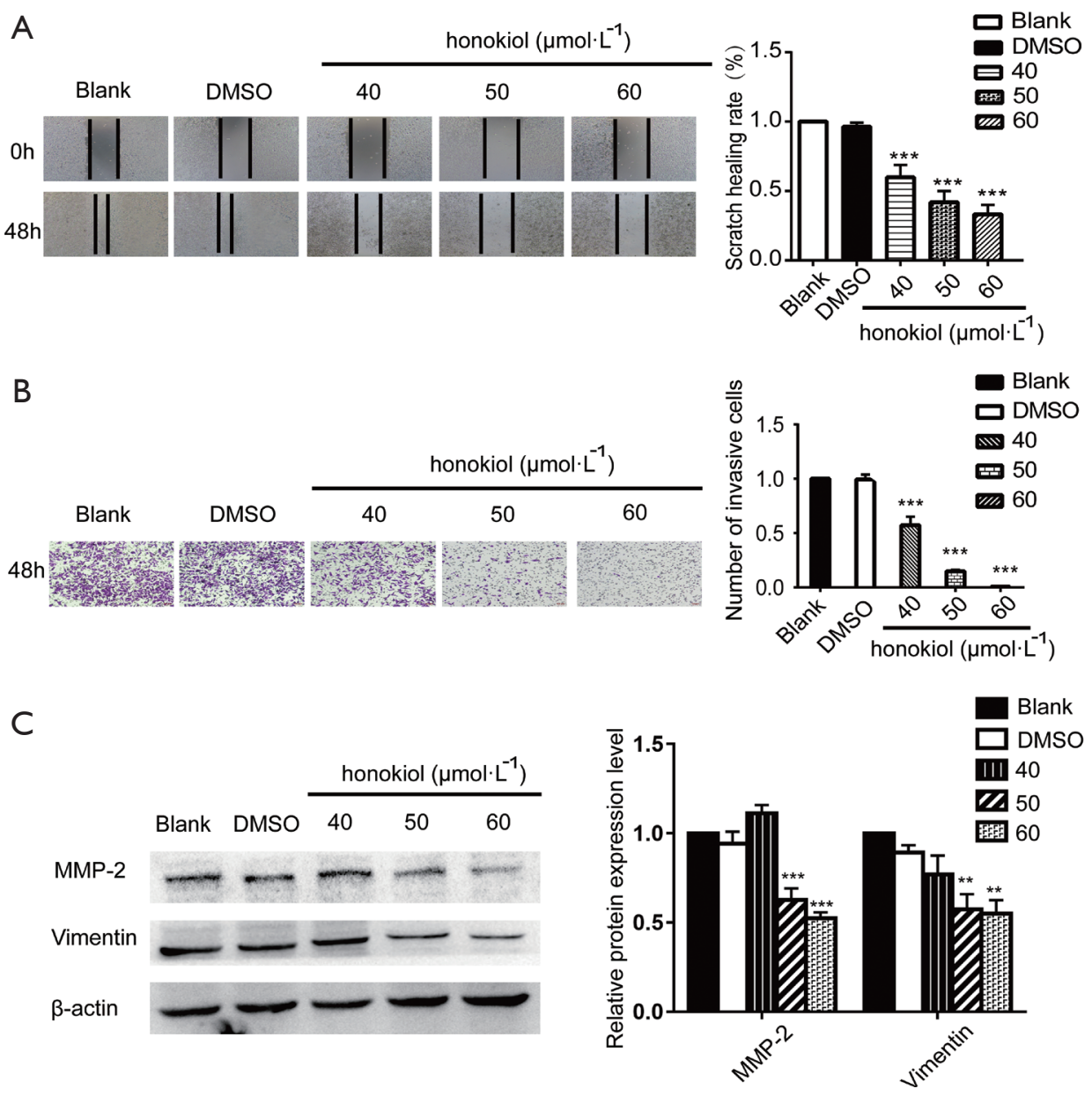

Figure 3 Honokiol significantly inhibits the invasion and migration of human breast cancer SK-BR-3. (A) Ability of cell migration was measured by wound healing assay (100x). (B) Ability of cell invasion was measured by Transwell assay (100x). (C) Protein expression level of vimentin and matrix metalloproteinase-2 (MMP-2). Each experiment was repeated 3 times. One-way analysis of variance was used for the statistical analysis. Data are expressed as mean \pm standard deviation. $\mathrm{P}<0.05$ indicates a statistically significant difference. ${ }^{* *} \mathrm{P}<0.01$, *** $\mathrm{P}<0.001$. DMSO, dimethylsulfoxide.

assay was used to detect the change of cell migration ability (Figure 3A). Compared to the blank control cells, honokiol was found to inhibit the ability of cell migration and was concentration dependent. Transwell analysis showed that, compared with the blank control group, the number of cells passing through the compartment membrane in the honokiol treatment group $(40,50$, and $\left.60 \mu \mathrm{mol} \cdot \mathrm{L}^{-1}\right)$ was significantly reduced $(\mathrm{P}<0.01)$ (Figure $3 B)$. Western blot was performed to further confirm that honokiol can reduce the invasion- and migrationrelated proteins expressed by cells, such as vimentin and MMP-2 $(\mathrm{P}<0.05)$ (Figure 3C). Taken together, these data demonstrate that honokiol can inhibit the invasion and migration ability of SK-BR-3 cells.

\section{Honokiol interferes with the Wnt/B-catenin signaling pathway in SK-BR-3 cells}

It has been reported in the literature that the activation of the Wnt signaling pathway is involved in the development of a number of cancers. Therefore, in the present study, we used Western blot to detect the effect of different concentrations of honokiol on Wnt signaling pathway activity in SKBR-3 cells (Figure 4). Compared with the blank control group, after SK-BR-3 cells were treated with 50 and $60 \mu \mathrm{mol} \cdot \mathrm{L}^{-1}$ honokiol, the expression level of $\beta$-catentin and its downstream protein c-Myc was significantly downregulated $(\mathrm{P}<0.01)$. We also tested the protein expression of GSK-3 $\beta$ and phosphorylated Gsk-3 $\beta$, 
the expression level of GSK-3 $\beta$ has not change but phosphorylated GSK-3 $\beta$ expression has decreased. Taken together, these data demonstrate that honokiol can effectively inhibit the occurrence and development of breast cancer by promoting apoptosis of SK-BR-3 cells while inhibiting their proliferation, migration, and invasion. The mechanism may be interference with the Wnt signaling pathway.

\section{Discussion}

Breast cancer is a malignant tumor that occurs in the epithelial tissue of the breast; it has a high rate of recurrence and a poor prognosis (13). Finding drugs with high efficiency, low side-effects, and low cost has become a research hotspot. The present study focused on the multiple inhibitory effects of honokiol on human breast cancer SKBR-3 cells and their specific mechanisms.

Apoptosis is a cell process; it is the autonomous and orderly death of cells controlled by genes. Its purpose is to maintain the stability of the cell's internal environment. Promoting tumor apoptosis is a relatively simple and efficient method to treat cancer patients (14). The Bcl2 protein family is closely related to cell apoptosis and also affects the development of cancer. Bcl-xl is a classic anti-apoptotic protein, and its expression changes affect tumor cell apoptosis (15). Apoptosis is also regulated by the caspase cascade. When caspase 3 receives the apoptotic signal, self-splicing occurs, causing cell apoptosis (16). The proliferation-related protein PCNA is the core of many important cellular processes in tumor cells, and its main role is to control tumor progression and prognosis (17). A large number of studies have confirmed that there are abnormal expressions of PCNA in the occurrence and development of various tumors (18-20). In the present study, we used crystal violet staining, MTT assay, and Western blot to confirm that 50 and $60 \mu \mathrm{mol} \cdot \mathrm{L}^{-1}$ honokiol can inhibit the proliferation of human breast cancer SKBR-3 cells. Subsequently, flow cytometry was used to detect the level of apoptosis, and Western blot was used to detect apoptosis and proliferation-related proteins, such as Bcl$\mathrm{xl}$, caspase 3, CC3, and PCNA, to explore the effects of honokiol on apoptosis and the proliferation of human breast cancer SK-BR-3 cells. Flow cytometric results showed that 50 and $60 \mu \mathrm{mol} \cdot \mathrm{L}^{-1}$ honokiol can cause obvious apoptosis of human breast cancer SK-BR-3 cells. Western blot also confirmed that when breast cancer cells were treated with 50 and $60 \mu \mathrm{mol} \cdot \mathrm{L}^{-1}$ honokiol for $48 \mathrm{~h}$, the expression level of the anti-apoptosis-related protein Bcl-xl was significantly

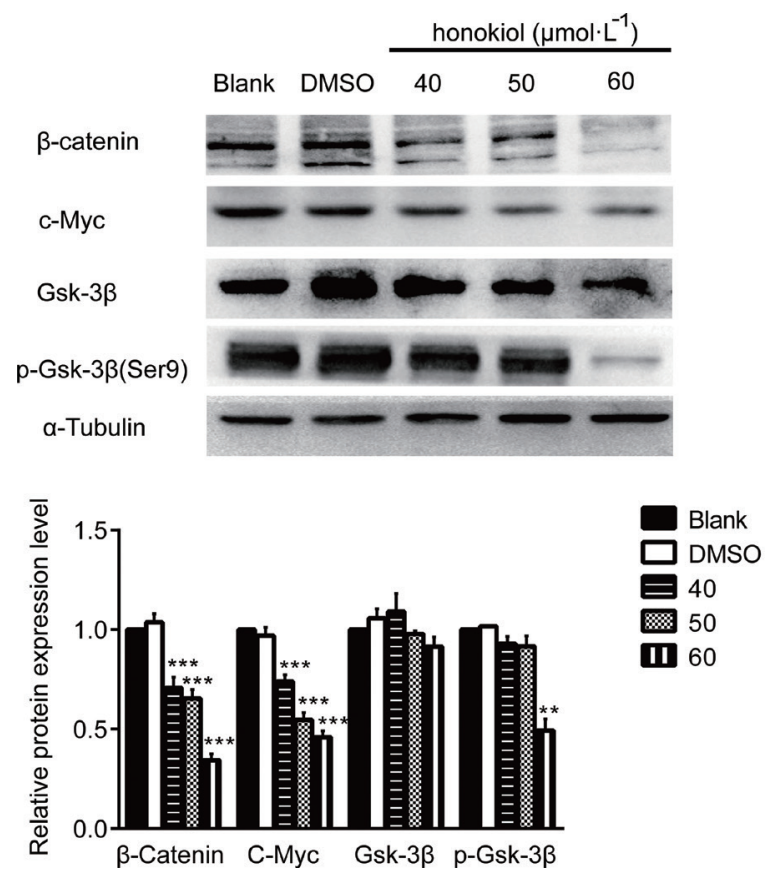

Figure 4 Honokiol significantly interferes with the Wnt signaling pathway in human breast cancer SK-BR-3 cells. Effects of honokiol on the expression levels of $\mathrm{Wnt} / \beta$-catenin pathway-related proteins

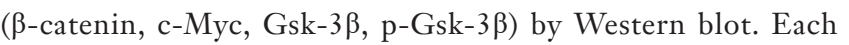
experiment was repeated 3 times. One-way analysis of variance was used for the statistical analysis. Data are expressed as mean \pm standard deviation. $\mathrm{P}<0.05$ indicates a statistically significant difference. ${ }^{* *} \mathrm{P}<0.01,{ }^{* * *} \mathrm{P}<0.001$. DMSO, dimethylsulfoxide.

reduced, the expression level of pro-apoptotic protein (CC3) increased, and the expression level of caspase 3 decreased. Honokiol was found to promote SK-BR-3 through cell apoptosis and inhibit its proliferation.

Epithelial-mesenchymal transition is a common biologic process of cancer cells. Epithelial cells undergo partial procedures to transform into a mesenchymal cell phenotype; the expression of vimentin is beneficial to the metastasis of tumor cells (21). MMPs are closely related to the metastasis of tumor cells. They help tumor cells to migrate by breaking down MMP proteins (22). In the present study, the wound healing assay, Transwell assay, and Western blot were used to detect the effect of honokiol on the migration and invasion of human breast cancer SKBR-3 cells and the expression of its related proteins MMP2 and vimentin. Experimental results showed that honokiol has a significant inhibitory effect on the migration and invasion of human breast cancer SK-BR-3 cells. 
Previously published studies have confirmed that the Wnt signaling pathway is involved in controlling the process and prognosis of breast cancer $(23,24)$. In the Wnt pathway, GSK-3 $\beta$ is upstream of $\beta$-catenin and regulates stability of $\beta$-catenin, when Serine 9 of GSK-3 $\beta$ is phosphorylated, its activity decreases, results in reduced $\beta$-catein degradation and Wnt pathway is activated (25). The downstream c-Myc protein is closely related to the occurrence and development of breast cancer (26). In the present study, Western blot confirmed that honokiol can downregulate the expression level of $\beta$-catentin protein in the Wnt signaling pathway, and at the same time downregulate the expression of its downstream protein c-Myc. We also detected the protein expression of GSK-3 $\beta$ and its phosphorylated form. Western blot showed that the expression level of phosphorylated GSK-3 $\beta$ (Ser9) was down-regulated, while the level of total GSK-3 $\beta$ expression was not significantly different, which interferes with the Wnt signaling pathway in breast cancer cells, thereby inhibiting breast cancer development. In summary, we found that certain concentrations of honokiol can effectively inhibit the occurrence and development of human breast cancer, as well as the proliferation, migration, and invasion of human breast cancer SK-BR-3 cells by effectively interfering with the $\mathrm{Wnt} / \beta$-catenin signaling pathway. The results of the present study provide new and effective evidence for honokiol as a safe and effective antibreast cancer drug.

\section{Acknowledgments}

Funding: None.

\section{Footnote}

Reporting Checklist: The authors have completed the MDAR reporting checklist. Available at http://dx.doi.org/10.21037/ tcr-20-3110

Data Sharing Statement: Available at http://dx.doi. org/10.21037/tcr-20-3110

Conflicts of Interest: All authors have completed the ICMJE uniform disclosure form (available at http://dx.doi. org/10.21037/tcr-20-3110). The authors have no conflicts of interest to declare.

Ethical Statement: The authors are accountable for all aspects of the work in ensuring that questions related to the accuracy or integrity of any part of the work are appropriately investigated and resolved.

Open Access Statement: This is an Open Access article distributed in accordance with the Creative Commons Attribution-NonCommercial-NoDerivs 4.0 International License (CC BY-NC-ND 4.0), which permits the noncommercial replication and distribution of the article with the strict proviso that no changes or edits are made and the original work is properly cited (including links to both the formal publication through the relevant DOI and the license). See: https://creativecommons.org/licenses/by-nc-nd/4.0/.

\section{References}

1. Jin HL, Kuzmiak CM, Cho E, et al. Characteristic Features of Breast Cancer in Women Aged $\leq 30$ Years. Hong Kong Journal of Radiology 2019;22:114-22.

2. Kono M, Fujii T, Lim B, et al. Androgen Receptor Function and Androgen Receptor-Targeted Therapies in Breast Cancer. JAMA Oncol 2017;3:1266-73.

3. Yang YS, Chen YL, Di GH, et al. Prognostic value of primary tumor surgery in de novo stage IV breast cancer patients with different metastatic burdens: a propensity score-matched and population-based study. Transl Cancer Res 2019;8:614-25.

4. Wang Y, Liu Z, Liu Q, et al. Honokiol Suppressed Pancreatic Cancer Progression via miR-101/Mcl-1 Axis. Cancer Manag Res 2020;12:5243-54.

5. Yan Y, Xu J, Mao G. Honokiol Suppression of Human Epidermal Growth Factor Receptor 2 (HER2)-Positive Gastric Cancer Cell Biological Activity and Its Mechanism. Med Sci Monit 2020;26:e923962.

6. Chiu CS, Tsai CH, Hsieh MS, et al. Exploiting Honokiolinduced ER stress CHOP activation inhibits the growth and metastasis of melanoma by suppressing the MITF and $\beta$-catenin pathways. Cancer Lett 2018;442:113-25.

7. Singh T, Katiyar SK. Honokiol, a phytochemical from Magnolia spp., inhibits breast cancer cell migration by targeting nitric oxide and cyclooxygenase-2. Int J Oncol 2011;38:769-76.

8. Wang WD, Shang Y, Li Y, et al. Honokiol inhibits breast cancer cell metastasis by blocking EMT through modulation of Snail/Slug protein translation. Acta Pharmacol Sin 2019;40:1219-27.

9. Pirsko V, Cakstina I, Priedite M, et al. An Effect of Culture Media on Epithelial Differentiation Markers in Breast Cancer Cell Lines MCF7, MDA-MB-436 and SkBr3. 
Medicina (Kaunas) 2018;54:11.

10. Colzani B, Pandolfi L, Hoti A, et al. Investigation of antitumor activities of trastuzumab delivered by PLGA nanoparticles. Int J Nanomedicine 2018;13:957-73.

11. Majumder M, Dunn L, Liu L, et al. COX-2 induces oncogenic micro RNA miR655 in human breast cancer. Sci Rep 2018;8:327.

12. Kunte S, Abraham J, Montero AJJC. Novel HER2targeted therapies for HER2-positive metastatic breast cancer. Cancer 2020;126:4278-88.

13. Ji JY, Chen JZ, Li JL, et al. "Chaihu Jia Longgu Muli Decoction" in the Treatment of Postoperative Hot Flashes in Breast Cancer: A Case Report. World Latest Medicine 2019;19:238.

14. Debelec-Butuner B, Kotmakci M, Oner E, et al. Nutlin3aLoaded Nanoparticles Show Enhanced Apoptotic Activity on Prostate Cancer Cells. Mol Biotechnol 2019;61:489-97.

15. Czabotar PE, Lessene G, Strasser A, et al. Control of apoptosis by the BCL-2 protein family: implications for physiology and therapy. Nat Rev Mol Cell Biol 2014; 15:49-63.

16. Zhao Y, Sui X, Ren H. From procaspase-8 to caspase-8: revisiting structural functions of caspase-8. J Cell Physiol 2010;225:316-20.

17. Lv Q, Zhang J, Yi Y, et al. Proliferating Cell Nuclear Antigen Has an Association with Prognosis and Risks Factors of Cancer Patients: a Systematic Review. Mol Neurobiol 2016;53:1553-9.

18. Liu DB, Yang L, Zhou YM, et al. Expression and clinical significance of HMGB1, Notch1 and PCNA in cervical cancer tissues. Chinese Journal of Family Planning 2018;26:793-7.

19. Yang X, Zou N, Li Q, et al. Significance in expression of RNF2 and PCNA proteins in esophageal squamous cancer cells. Carcinogenesis, Teratogenesis and Mutagenesis 2018;30:254-7.

20. Paradiso A, Rabinovich M, Vallejo C, et al. p53 and PCNA expression in advanced colorectal cancer: response to chemotherapy and long-term prognosis. Int J Cancer 1996;69:437-41.

21. Savagner P. Epithelial-mesenchymal transitions: from cell plasticity to concept elasticity. Curr Top Dev Biol 2015;112:273-300.

22. Mori M, Mimori K, Shiraishi T, et al. Analysis of MT1MMP and MMP2 expression in human gastric cancers. Int J Cancer 1997;74:316-21.

23. Yin $\mathrm{P}$, Wang $\mathrm{W}$, Zhang $\mathrm{Z}$, et al. Wnt signaling in human and mouse breast cancer: Focusing on Wnt ligands, receptors and antagonists. Cancer Sci 2018;109:3368-75.

24. Wang Z, Li B, Zhou L, et al. Prodigiosin inhibits Wnt/ $\beta$-catenin signaling and exerts anticancer activity in breast cancer cells. Proc Natl Acad Sci U S A 2017;113:13150.

25. Tejeda-Muñoz N, Robles-Flores M. Glycogen synthase kinase 3 in Wnt signaling pathway and cancer. IUBMB Life 2016;67:914-22.

26. Wang J, Li M, Chen D, et al. Expression of C-myc and $\beta$-catenin and their correlation in triple negative breast cancer. Minerva Med 2017;108:513-7.

(English Language Editor: R. Scott)
Cite this article as: Shi H, Wang Y, Yao M, Zhang D, Fang W, Zhou T, Gan D, Yue S, Qian H, Chen T. Honokiol inhibits the growth of SKBR3 cells. Transl Cancer Res 2020;9(12):7596-7604. doi: $10.21037 /$ tcr-20-3110 